\title{
Street trees in Paris are sensitive to spring and autumn precipitation and recent climate changes
}

\author{
Ambre A. J. David ${ }^{1}$ - Anaïs Boura ${ }^{2}$. Jean-Christophe Lata ${ }^{1,3}$ - Aleksandar Rankovic ${ }^{1,4}$. $^{2}$ \\ Yvan Kraepiel $^{1} \cdot$ Coralie Charlot $^{1} \cdot$ Sébastien Barot $^{1} \cdot$ Luc Abbadie $^{1} \cdot$ Jérôme Ngao $^{5}$
}

\begin{abstract}
Determining the main factors causing urban tree decline is becoming essential for sustaining their health and survival. Understanding responses of tree growth to urban environments and climate change throughout tree life span is thus necessary. To explore these questions, a dendrochronological study exploring past climate-tree growth relationships was conducted on street and park silver lindens in Paris, according to different DBH classes used as a proxy of tree age, and using climatic data for the 1970-2013 period. Younger urban silver lindens presented high sensitivity to climate with highest growth rate. In comparison with park trees, street trees had higher sensitivity to climate and lower growth rates. Climatic and pointer years analysis pointed out the importance of drought characterization in order to understand its potential impact on tree annual growth and functioning. Urban silver
\end{abstract}

lindens growth is mainly and strongly correlated with precipitations and especially in autumn and spring. Finally, our study on temporal evolution between climatic factors and growth through 1970-2013 periods showed a stronger stability between growth and precipitation only in October and revealed quick climatic changes since 40 years impacting the relation between tree growth and climate. Our study highlights that an optimized irrigation management, specifically in respect of tree phenology, could contribute to maximizing silver linden functioning and survival in Paris under climate change.

Keywords Climate change - Climate-growth relationship . Dendrochronology $\cdot$ Pointer years $\cdot$ Street trees $\cdot$ Tilia tomentosa Moench $\cdot$ Water stress

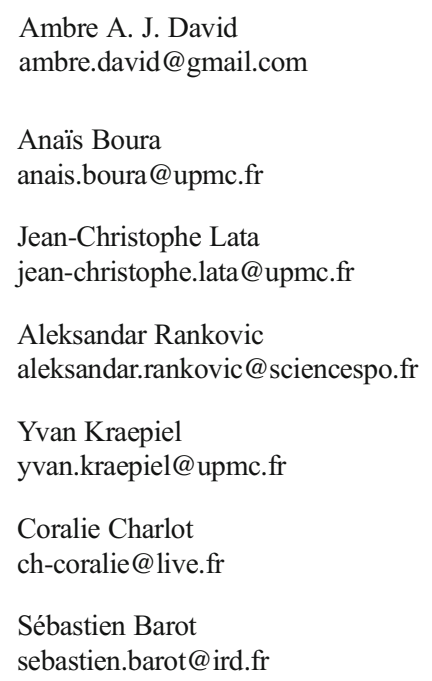

Luc Abbadie

luc.abbadie@upmc.fr

Jérôme Ngao

jerome.ngao@inra.fr

1 Sorbonne Universités, UPMC Univ. Paris 06, IRD, CNRS, INRA, UPEC, Univ Paris Diderot, Institute of Ecology and Environmental Sciences, iEESParis, 4 place Jussieu, 75005 Paris, France

2 Center for Research on Palaeobiodiversity and Palaeoenvironments, 57 rue Cuvier, 75231 Paris Cedex 5, France

3 Department of Geoecology and Geochemistry, Institute of Natural Resources, Tomsk Polytechnic University, Lenin Avenue, 30, 634050 Tomsk, Russia

4 Institute for Sustainable Development and International Relations, Sciences Po, 27 rue Saint Guillaume, F-75007 Paris, France

5 UCA, INRA, UMR 547 PIAF, 63000 Clermont-Ferrand, France 


\section{Introduction}

An increasing attention has been paid to urban trees in recent decades, for their role in supporting urban biodiversity and providing ecosystem services such as urban heat island mitigation, air pollution reduction or carbon storage (Pataki et al. 2011; Díaz-Porras et al. 2014). However, many unknowns remain about their functioning in urban environments. Especially in a global change context, their long-term longevity is difficult to assess. A recent meta-analysis reported a typical mean life expectancy for street trees of 19-28 years, and an annual mortality rate of 3.5-5.1\% (Roman and Scatena 2011). In Paris City (France), life expectancy of street trees is around 80 years associated with an annual mortality rate of $1.5 \%$. This rate increase up to $8-10 \%$ for younger trees after the first 3 years of plantation (Mairie de Paris 2016). These figures are quite low given that some common planted species, such as Tilia spp., have a longevity that can be up to 1000 years (Radoglou et al. 2009). Despite increased willingness to green urban areas, planting more trees is challenging because of increasing threats on their health and survival (Roman 2014).

Previous studies listed different explanatory factors to urban tree decline. Among them, pollution, pruning, soil conditions or individual tree characteristics could be involved in urban tree decline (Roberts 1977; Kjelgren and Clark 1992; Lin et al. 2006; Nielsen et al. 2007; Sjöman et al. 2012; Moser et al. 2016b). However, several studies have shown that drought could be the main inciting factor impacting urban trees health and survival (Roberts 1977; Apple and Manion 1986; Clark and Kjelgren 1989; Whitlow et al. 1992; McCarthy and Pataki 2010; Gillner et al. 2013; Gillner et al. 2014; Vico et al. 2014). Indeed, reduced precipitation, urban impervious ground surface and absent irrigation may increase water stress (Whitlow and Bassuk 1987; Clark and Kjelgren 1989). It is also generally predicted that trees at urban sites have higher water loss than in natural forests due to increased evapotranspiration demands (Whitlow et al. 1992; McCarthy and Pataki 2010). In addition, the accumulation of drought events during tree life could be an important driver behind the lower growth and life expectancy of street trees (Ciais et al. 2005; Gillner et al. 2013).

Investigating long-term street tree growth could also help understanding their responses to climate, and anticipating their future behavior under climate change (Oldfield et al. 2013). As tree physiology changes with age, street trees of different ages should respond differently to present and future climates, implying different requirements in terms of adapted management practices (Clark and Matheny 1992). Differences in age-specific responses of trees to climate are often addressed in literature (Carrer and Urbinati 2004; Linares et al. 2013) but, to our knowledge, no such study was conducted on street trees. In this context, dendrochronology is a useful tool to study the relationship between tree growth and climatic factors such as temperature and precipitation in urban environment (Fritts 1976; Sjöman et al. 2012).

The present study proposes a dendrochronological approach that explores the relationships between past climate and past growth of the silver linden (Tilia tomentosa Moench) in Paris City, and their dependence to tree age and land-use type. In Paris, the Tilia genus represents more than $10 \%$ of planted trees in streets, with a majority of silver lindens (APUR 2010). Tilia tomentosa is a fast-growing species with large and well defined rings in the juvenile phase (Radoglou et al. 2009). The aim of this study is to (i) characterize the growth patterns of young and adult trees living in streets or parks, (ii) identify the main climatic drivers that impacted past tree growth during the period 1970-2013 (the maximum common period to all wood cores and climatic data), and (iii) identify potential recent changes in the relation between urban silver linden growth and climatic factors. This study contributes to the general knowledge about silver linden functioning and dendrochronological potential, enhances our understanding of urban tree sensitivity to climatic factors and land-use types, and provides insights to managers for answering current and future urban tree water requirements.

\section{Materials and methods}

\section{Study area and sampling design}

The study was conducted in Paris city, France $\left(48.8534^{\circ} \mathrm{N}\right.$; $2.3488^{\circ} \mathrm{E}$ ). Paris silver linden trees (Tilia tomentosa Moench) come from commercial nurseries of several European countries and are planted with a Diameter-atBreast-Height (DBH; $1.30 \mathrm{~m}$ ) between 6 and $8 \mathrm{~cm}$, at an age of 8 to 10 years (Paris Green Space and Environmental Division, pers. comm.). The studied trees were chosen in two different environments (hereinafter referred as land-use types): 70 within streets and 15 in parks. Both land-use types share a common type of climate and a common soil and tree management, as urban tree management rests on similar principles since the nineteenth century and the Haussmannian works (Pellegrini 2012). When a new tree is planted, a pit of about $10 \mathrm{~m}^{3}$ is dug and filled with imported soil from surrounding peri-urban agricultural areas. Plantations are then irrigated every two weeks and during three years. Afterwards, no management practice other than pruning is performed (Pellegrini 2012). In each of the selected streets, only trees with either bare or drain-covered soils were selected to avoid important differences in terms of rooting conditions and water availability (Rahman et al. 2011). The 6 selected parks or open spaces were built from the second part of the nineteenth century to the mid of the twentieth century. Since severe wounds could affect climatic signal in tree-rings chronology (Neuwirth et al. 2007), only vigorous trees were 
selected after a visual assessment (Visual Tree Assessment protocol, Mattheck and Breloer 1994). The 85 chosen trees were grouped according to three DBH classes. Because no information on tree age, such as plantation date, was available, the DBH was preliminary used as an age proxy as follows: Class 1 (7 $\mathrm{cm}<\mathrm{DBH}<14 \mathrm{~cm}$, young trees), Class 2 (33 $\mathrm{cm}<\mathrm{DBH}<43 \mathrm{~cm}$, young adults), and Class $3(57 \mathrm{~cm}<$ DBH $<73 \mathrm{~cm} \mathrm{~cm}$, adults). Sampled streets and parks were spread across the city, and were also selected according to their proximity and the presence of all three DBH classes (Fig. 1).

\section{Climatic data}

Climatic data were recorded for the 1970-2014 period at the Montsouris meteorological station (Paris: $48.8566 \mathrm{~N}$; 2.3366E - Météo France station 07156). Parisian climate is temperate, sub-Atlantic (Crippa et al. 2013). For the targeted period of 1970-2013 (chosen as climatic data and a sufficient number of trees were available), mean annual temperature was $12.25^{\circ} \mathrm{C}$ (Fig. 2). Mean temperature for the coldest months (January, February and December) averaged $4.8{ }^{\circ} \mathrm{C}$ while for the warmer months (June, July and August) it averaged $18.0^{\circ} \mathrm{C}$. Mean annual precipitation was $637 \mathrm{~mm}$ (Fig. 2), with a maximum in May and July ( $>60 \mathrm{~mm}$.month ${ }^{-1}$ ) and a minimum in February, March, April and September $\left(<48 \mathrm{~mm}\right.$. month $\left.^{-1}\right)$. Concomitant lowest precipitation - highest temperatures were observed from June to September with a maximum in July and August. Potential evapotranspiration (PET, according to the Penman-Monteith equation - Allen et al. 1998) and total radiation data were only available for the 1978-2013 period. Mean PET was $68.24 \mathrm{~mm}$ on average (Fig. 2), with the highest values in June and July (130.71 and $139.60 \mathrm{~mm}$ respectively), and the lowest values in November, December and January $(15 \mathrm{~mm})$. Annual mean of total radiation was around $32,472{\mathrm{~J} . \mathrm{cm}^{-2}}^{\text {(Fig. 2), with }}$ the highest values in May, June and July $(53,352,56,230$ and $56,900 \mathrm{~J} . c m^{-2}$ respectively), and the lowest values in December and January (ca. $8000 \mathrm{~J} . \mathrm{cm}^{-2}$ ).

\section{Tree-ring measurements and dendrochronogical analysis}

Tree wood cores were collected in March (street trees) and September 2014 (park trees) with a sterilized Pressler increment borer (coretax HAGLOF; length: $400 \mathrm{~mm}$; diameter: $5 \mathrm{~mm}$ ). Due to tree health policy of Paris municipality, only one core was sampled per tree. Cores were then prepared following standard methods (Schweingruber 1996; Bräker 2002). We have rigorously retained cores with the least anomalies, minimizing the risk of errors during measurements and the noise present in the chronologies (Table 1). Ring widths were measured using a Lintab measurement table (Rinntech, Heidelberg, Germany) at a resolution of $1: 100 \mathrm{~mm}$, leading to an individual chronology per core.

All the following dendrochronological analyses were performed using DENDRO and CLIMAT packages developed by (Mérian 2012a; Mérian 2012b) under R 3.2.0 (R Development Core Team 2011), as for statistical analyses. First, a master chronology was built using a biweighted robust mean in order to relieve the impact of outliers (Cook and Kalriukstis 1990) over the 1970-2013 period (Fig. 3). Each individual chronology was then cross-dated using the visual inspection of core samples with a $40 \times$ binocular magnifier (Leica Microsystems, Nanterre, France) associated with a visual comparison using the skeleton plot method (Cropper 1979), between individual chronologies and the chosen master chronology (Maxwell
Fig. 1 Study sites location map in Paris City (France). Study sites marked as circled (street trees) and triangles (park trees), colors coded as light grey (class $1, \mathrm{DBH}$ $7-14 \mathrm{~cm}$ ), grey (class 2, DBH $33-$ $43 \mathrm{~cm}$ ), and black (Class $3, \mathrm{DBH}$ $57-73 \mathrm{~cm}$ )

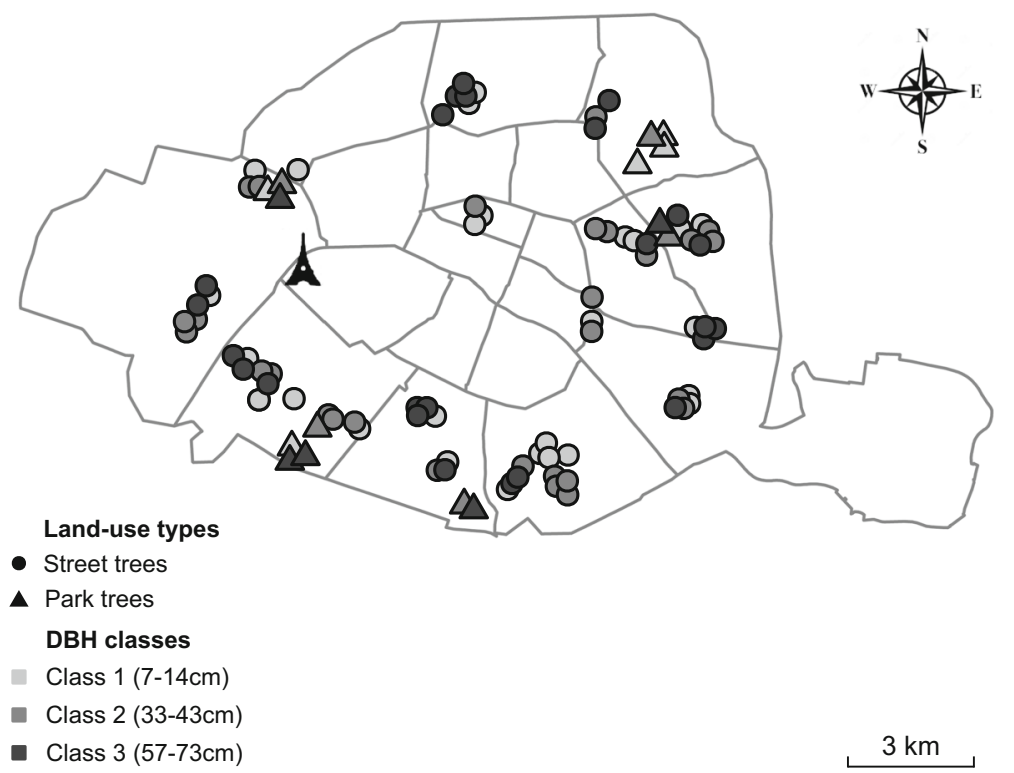


Fig. 2 Annual average of monthly temperatures (on the top left) and of annual sum of total precipitations (on the top right) for the period 1970-2013. Annual average of monthly total radiation (on the bottom left) and of potential evapotranspiration (on the bottom right) for the 19782013 period in Paris City (France). Black line represents mean or sum, and the grey area represents standard error (SE)
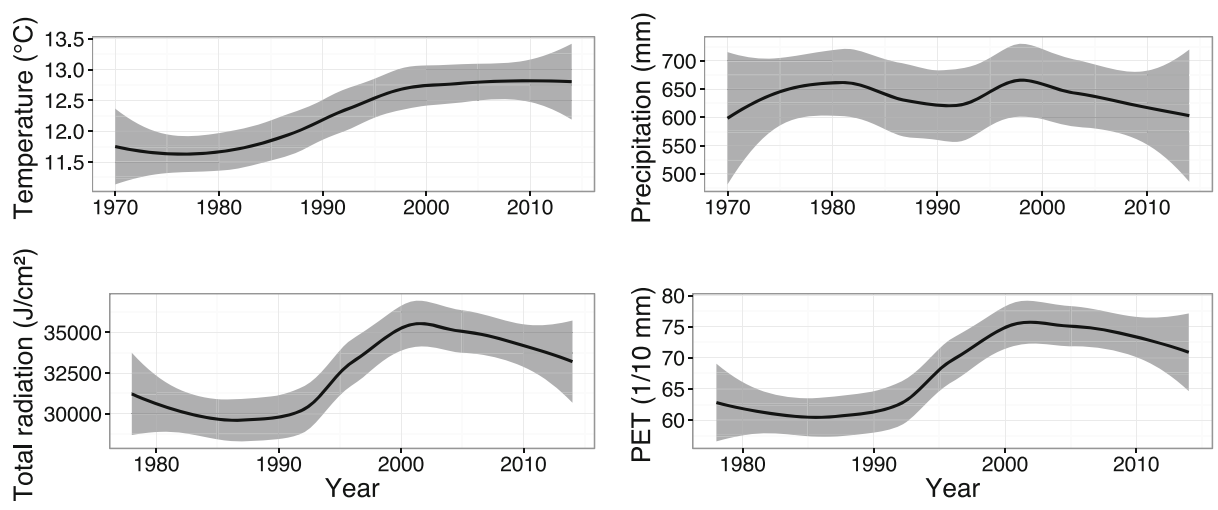

et al. 2011). The quality of the cross-dating process was checked using the COFECHA program (Grissino-Mayer 2001). The raw tree-ring width series were then standardised in order to obtain growth indices (Fritts 1976). In a first step, a negative exponential or a non-ascending straight lines function was fitted on raw tree-ring width series, and growth indices were calculated by dividing the measured ring width by the ring width predicted by the function. This allowed removing growth trends due to tree age and short term environmental variability (Fritts 1976). In a second step, first-standardised data were fitted by a cubic spline. As for the first step, growth indices were calculated by division to allow removing environmental and management processes affecting tree growth at 25 years scale (Cook and Peters 1981).

The effects of land-use type and DBH class were then analyzed with robust models for unbalanced designs. Differences between dendrometric parameters (DBH, age and growth rate) from raw chronologies were statistically tested with a general linear model (GLM). Ring width differences were tested with a linear mixed-effect model with year and tree as random effects. These models where then subjected to Tukey contrasts post-hoc tests. Differences were considered significant at $p<0.05$. For each factor, mean sensitivity was calculated on standardized growth indices, as it describes the intensity of tree growth response to year-to-year environmental variability (Biondi and Qeadan 2008). A high mean sensitivity (above 0.30 , as presented by Grissino-Mayer 2001) indicates a strong influence of climatic factor on growth. The program also estimated the first order autocorrelation (Ac1) that conveys the degree of correlation between current and previous year growth (Fritts 1976) and the expressed population signal (EPS) used to assess the quality of our chronology for climatic analysis (Briffa and Jones 1990). An EPS value above 0.85 indicated that the climatic signal of the population was reliable (Wigley et al. 1984).

\section{Climate-growth analysis and pointer years}

Correlation analyses were performed to assess tree growth response to climatic conditions. When all trees from streets and parks were considered, the EPS value for the period 1970-2013 was above the 0.85 critical threshold (0.89; Table 1). In consequence, bootstrapped correlations coefficients (BCC) calculations were performed on the entire sampled population of silver lindens in Paris City. In this procedure, standardized chronologies were correlated to time series of monthly mean temperatures, monthly sum of precipitation, monthly mean PET and monthly mean total daily radiations from September of the previous year (namely n-1) to November of the current year (namely n), period limiting the growing season for silver lindens in Paris. A bootstrap method had to be used due to the non-independence of tree rings within each individual tree. The program estimated BCC at the end of 1000 re-sampling of a random selection of 11 years during the 1970-2013 period to detect significance level (95\% of BCC significant with a $p$-value $<0.05$; Guiot 1991) according to two different methods. First, BCC calculation round was performed considering the entire temporal window 1970-2013 (Blasing et al. 1984) for precipitation and temperature and from 1978 to 2013 for PET and total radiation. Second, BCC were calculated with year-to-year moving methods. A temporal window of 30 years was the best compromise that we could make for such a short period as 1970 2013. This allowed detecting temporal instability of the relation between intra-annual climatic factors and growth (Biondi and Waikul 2004).

Relationships between growth and extreme climatic events were explored using pointer years and anomalies of precipitation and temperature. Pointer years were calculated with the method described by Becker (1989) and performed with POINTER package developed by Mérian (2012a). Positive pointer years are defined according to exceptionally wide tree-rings and negative years with exceptionally narrow tree-rings, appearing concurrently within the same group of trees (Schweingruber 1990). Then, monthly anomalies of precipitation and temperature were calculated for these pointer years by a first step of standardization of raw climatic series (Mérian 2012b) and, in a second step, by normalizing to a standard deviation of one and a mean of zero using the 33year monthly average over the 1970-2013 period. 


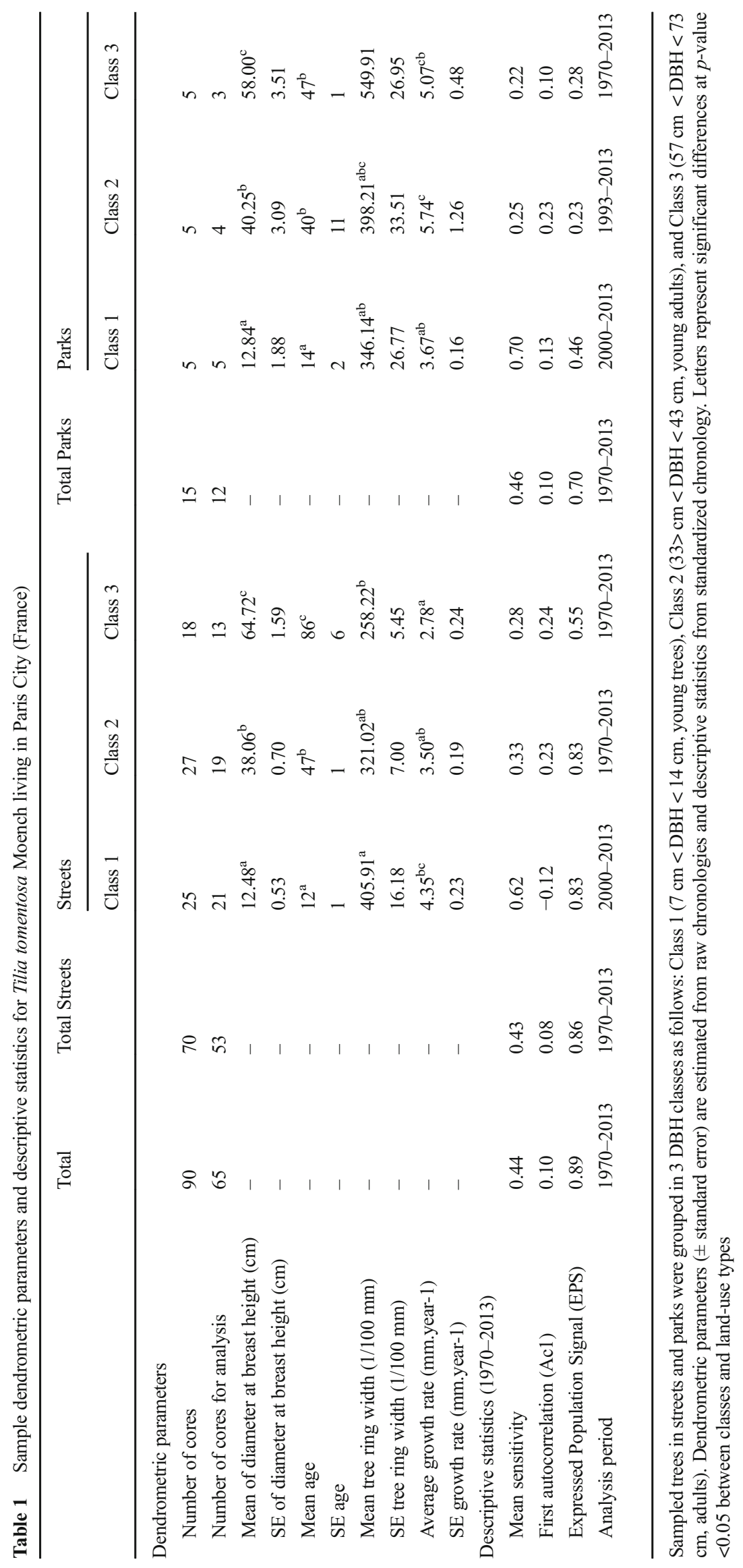


Fig. 3 Master chronology for Tilia tomentosa Moench in Paris City (1970-2014) with pointer years (represented by dashed lines). Sample depth represents the total number of tree available for ring width index calculation in a year

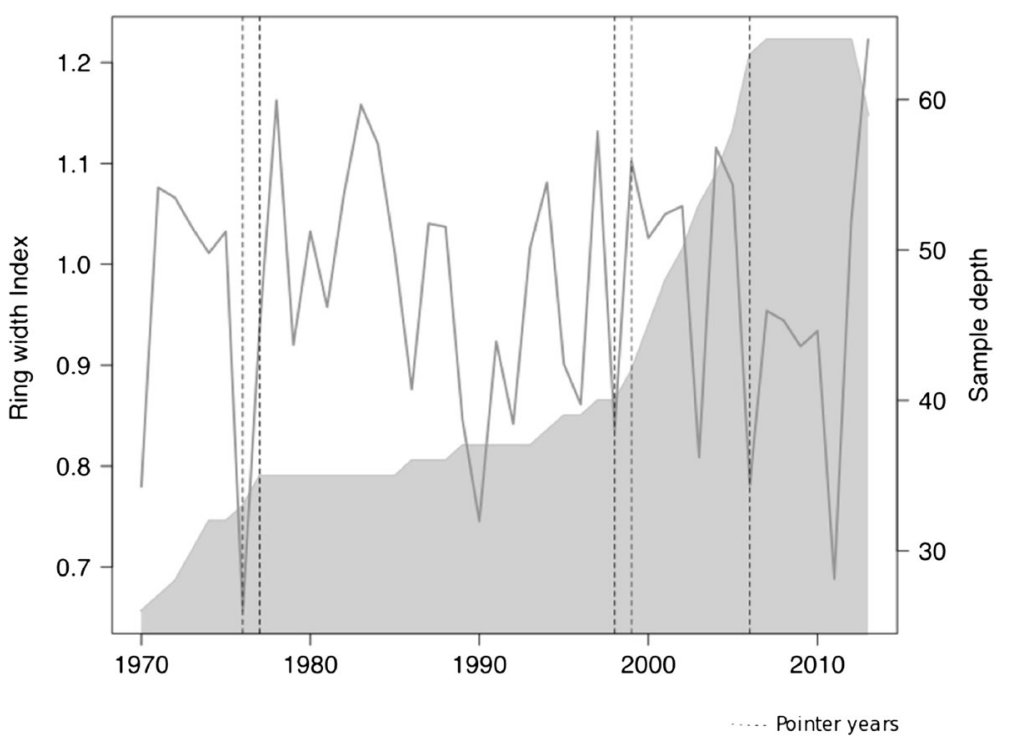

Importance of spring and autumnal weather conditions

According to the BCC calculated over the entire 1970-2013 period, growth indices were significantly positively correlated to precipitation of October of the previous year (October n-1) and May of the current year (May n) (Fig. 4). For the other months, the BCC with precipitation were not significant. A significant negative correlation between temperature and growth index was only found for May $\mathrm{n}$. The BCC for PET were not significant whatever the considered month. The BCC calculated between total radiation and growth index were only significantly negative for October n-1.

Significant negative pointer years were identified for 1976, 1998, and 2006 while 1977 and 1999 were significantly positive. Among growth indices, there were several occurrences of coupled years, where the first year displayed negative growth and the second year displayed positive growth. This phenomenon occurred e.g. in 1976/1977 and 1998/1999 (Figs 3 and 5). The negative years had generally stronger precipitation deficits $(\sigma)$ that were close to or higher than -0.5 (Fig. 5). For our pointer years, precipitation anomalies $\sigma$ were higher than temperature anomalies, which stayed close to 0 . The negative years were also characterized by more frequent deficit of precipitation for at least 7 to 12 out of 15 studied months. Regarding the two significant positive years for growth, anomalies for precipitation remained either close to 0 or slightly negative, denoting low deficits of precipitation during five to six months.

\section{Stability of the climate-growth relationship (1970-2013)}

The BBC computed during a 30 -year moving window between 1970 and 2013 involved the same meteorological variables at the same monthly scale (Fig. 6) than for the fullperiod analysis. The BCC were significant for precipitation 
Fig. 4 Correlation between Tilia tomentosa Moench growth index and intra-annual climatic data in Paris City (1970-2013). Dark grey bars indicate significant BCC, error bars express $95 \%$ confidence intervals. The month $\mathrm{n}-1$ is for previous year whereas month $\mathrm{n}$ is for current year
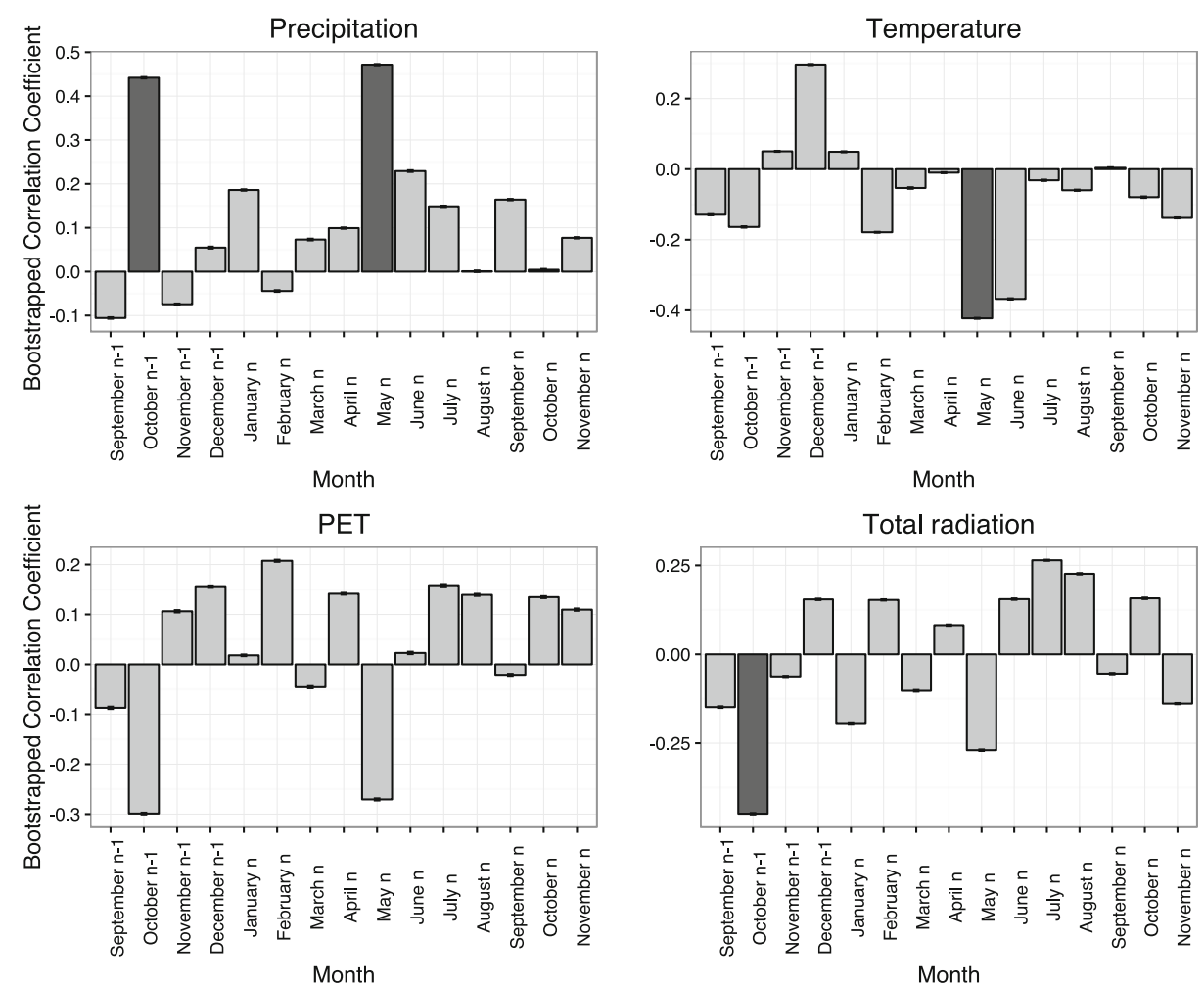

in October n-1 (most of the 30-y periods) and in May n (for the 1970-1999 period only). Thus, BCC values for precipitation of October n-1 appeared quite stable with respect to those for May $n$ through the whole study period. Temperature was not significantly correlated to growth indices. The same occurred for the relationships between growth indices and PET, and between growth indices and total radiation, whatever the 30year temporal window over the 1978-2013 period.

\section{Discussion}

\section{Radial growth comparison and tree response to climate}

Our results have shown that, in Paris, street trees had a lower growth rate than park trees. Other common urban hardwood species has been shown to have a reduced growth compare to rural conspecifics (Meyer 1982; Kjelgren and Clark 1992; Quigley 2004; Roberts et al. 2006; Zhao et al. 2016; Moser et al. 2016a). But opposite trends were also observed (Gregg et al. 2003; Evans 2010). These opposite results suggest that tree response to urban stress could be quite different according to several factors (Quigley 2004). For instance, urban air pollution could impact tree health in parks and streets (Lu et al. 2010). The spatial inhomogeneity of air pollution in urban streets is well known (Capannelli et al. 1977; Vardoulakis et al. 2002). In Paris, trees from streets with heavy traffic could bear air pollution concentrations up to 2 times higher than trees from surrounding streets (AirParif 2017). Thus, the higher exposure of street trees to air pollutants could contribute to explain their lower growth than park trees. However, in some cases and contrary to what is expected, air pollution could also stimulates photosynthesis through high carbon dioxide dinitrogen and warmer temperatures (Gregg et al. 2003; Takagi and Gyokusen 2004). Moreover, it also has been found that urban areas could show lower cumulative ozone exposures compared to rural sites (Gregg et al. 2003).

Pruning could also partly explain growth reduction in street tree. Tree management in Paris is usually limited to a slight pruning policy applied both for park and street trees (Paris Green Space and Environmental Division, pers. Comm). In addition to changes in the remobilization of reserves, Lin et al. (2006) have shown that pruning can lead to smaller annual rings. Similarly, Wang et al. (2003) have reported that DBH was significantly decreased due to pruning in Taiwania cryptomerioides. However, Maurin and DesRochers (2013) have found that pruning in poplar increased net photosynthesis of residual foliage, leaf nitrogen concentrations, and reduced root NSC reserves. Furthermore, pruned trees in their study, also appear to have higher stomatal conductance, suggesting that they may have higher resistance to drought.

Furthermore, soil conditions are also known to influence tree growth. In urban area, due to insufficient drainage, anaerobic conditions in flooded soils can cause the decline of trees growing in compacted soils (Harris et al. 1994; Sæbø et al. 2003). Indeed, the compaction of the soil is an abiotic stress well known in urban environment (Roberts 1977). Nielsen et al. (2007) have shown lower water retention capacities in standard 
Fig. 5 Anomalies in standard deviation unit $(\sigma)$ of temperature (black bars) and precipitation (grey bars) during negative (upper graphs) and positive (bottom graphs) pointer years

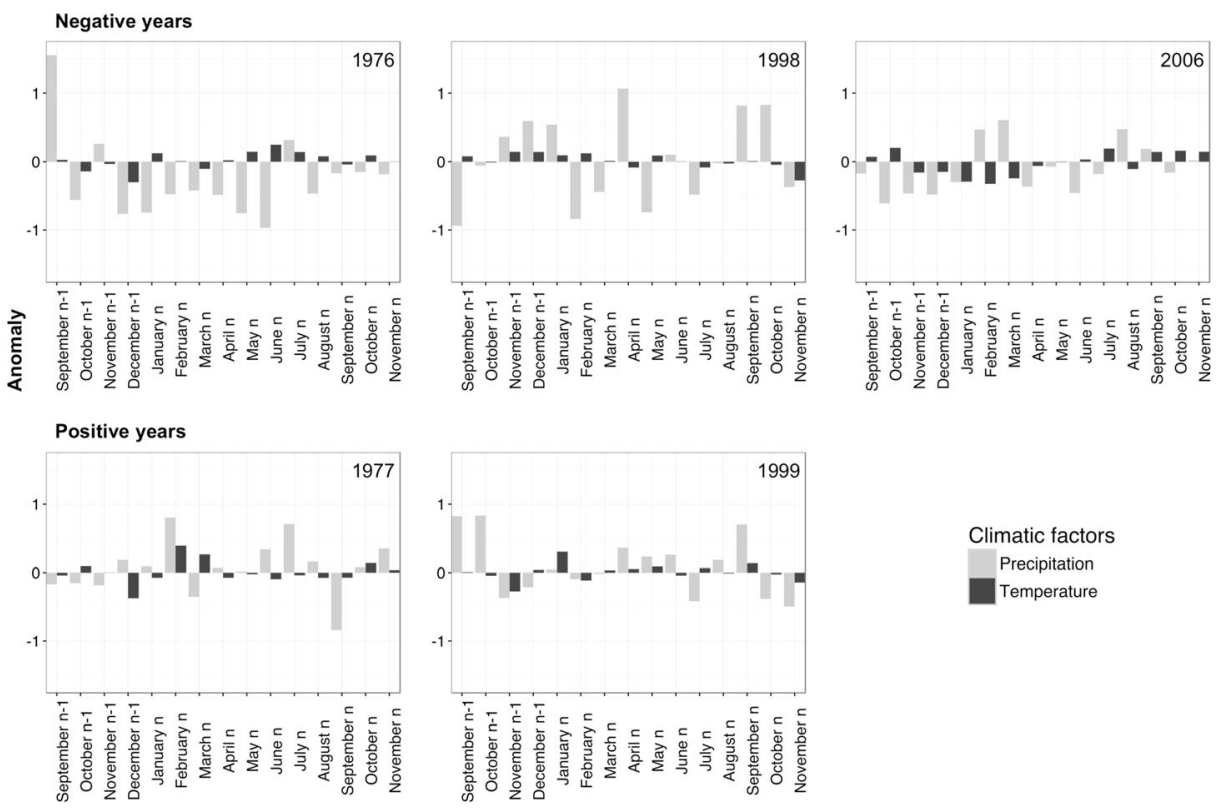

pavement street soils than in park due to coarser substrates in planting pits. The authors also observed a high variability in water retention capacities for street plantations associated with a high variability in drainage. However, water loss from street soils seems also much faster directly after rain, with an exponential decrease in the first 10 days, while this decrease seems more progressive for those in parks (Nielsen et al. 2007).
Nevertheless, the major difference between our two landuse types (i.e. park and street) is the much larger area of unsealed vegetated soil in parks, as pit dimension and soil exported are usually equivalent. Thus, the limited growth of street trees compared to park trees in Paris could be explained by a lower photosynthetic carbon assimilation due to water stress (Sieghardt et al. 2005). Water deficit induces stomata
Fig. 6 Bootstrapped Correlation Coefficient (BCC) calculated over 30-year moving periods between growth indices and four meteorological variables (from 1970 to 2013 for precipitation and temperature and from 1978 to 2013 for PET and Total radiation). White stars indicate significant BCC. Month n-1 expresses the month for the previous year whereas Month $\mathrm{n}$ indicates the month of the current year
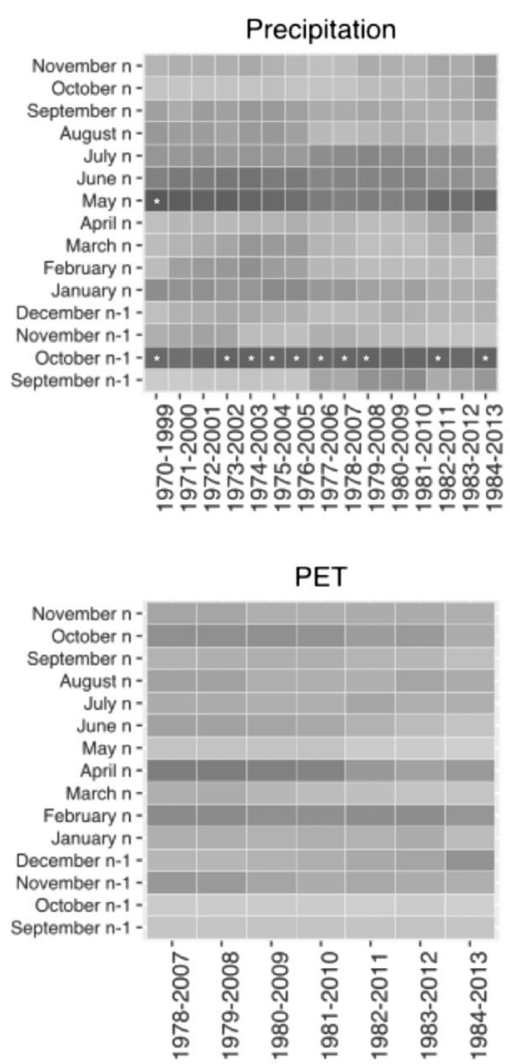

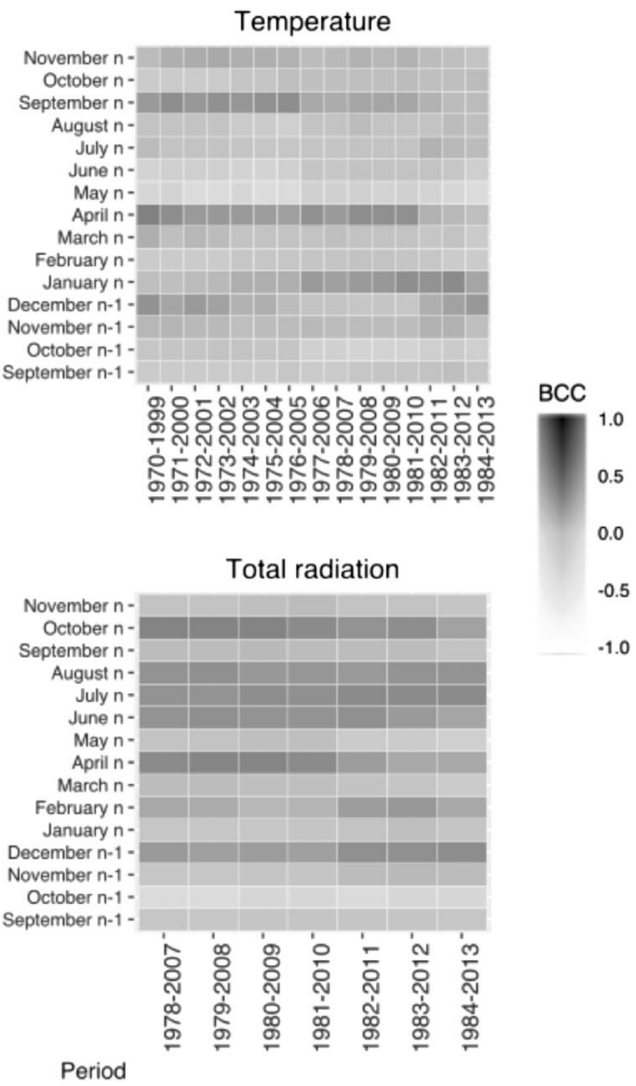


closure and the reduction of carbon uptake through photosynthesis (Petersen and Eckstein 1988). Furthermore, we have observed that growth rate decreases for street silver lindens. This could indicate that water stress undergone by trees in streets influenced directly the amount of aboveground carbon fixed, likely as a trade-off between growth and storage. Indeed, it has already been demonstrated that trees growing under conditions of high environmental stress such as severe water stress (Gruber et al. 2012) show high levels of stored non-structural carbohydrates (NSCs) associated with, or despite, a reduced growth (Simard et al. 2013).

The dendrochronological approach allows studying more in details the differences in climate-growth relationships between land-use types and/or age classes. However, in our study, the EPS analysis did not allow separating the respective influence of these factors. To go further, it would be essential to increase the number of studied trees, especially in parks (Mérian et al. 2013). At least 53 individuals have been necessary in order to get a 0.86 EPS value (Table 1). However, this number can be reduced for younger trees, as our results showed an EPS value of 0.83 for only 21 individuals and higher sensitivity to climate. However, a previous study highlighted the importance of incorporating different aged tree in chronology in order to have the most representative climatic signal (Wang et al. 2009). Besides, for street trees, between-tree variations in growth conditions, e.g. orientation of the street, size of the neighboring buildings, could diminish the strength of the common climatic signal. Gillner et al. (2013) found in urban oak chronologies a higher level of noise than in forest sites due to human activities that degrade the strength of growth-climate relations. It is well known that trees usually respond to climate variations at the regional scale but the variability of radiation loading, evaporative demands or soil characteristics in the mosaic urban environment is extremely high, making difficult to characterize the general microclimate encountered by individual trees (Gulyás et al. 2006; Moser et al. 2016b; Rahman et al. 2017).

\section{Importance of spring and autumnal weather conditions}

In this study, silver lindens growth was related to precipitation of October n-1 and May n (Fig. 4). The correlation with precipitation was constantly positive, suggesting a strong and positive influence of a sufficient water supply for growth (Lebourgeois et al. 2003). In addition, the correlation values for precipitation were also constantly higher than those for temperature, expressing that precipitation probably play the main role in the stimulation of cambial activity (Marion et al. 2007).

Fall phenology (i.e., leaf senescence and dormancy) remains little studied and still poorly understood (Xie et al. 2015). However, it is usually admitted that, in temperate climate, unfavorable climate in fall (such as frost, cold, water stress/drought, heat-stress), could affect mechanisms such as nutrient resorption during leaf senescence. Drought could curtailed nutrients resorption by causing rapid leaf death (Marchin et al. 2010; Xie et al. 2015). Thus, favorable climate during the autumn $n-1$ could boost carbohydrate storage (Michelot et al. 2012), and increase the amount of relative extractable water, which is important for earlywood formation and bud break during the following spring (Barbaroux and Bréda 2002). This could explain the positive influence of precipitation in October $\mathrm{n}-1$.

Interestingly, correlation for precipitation in May $\mathrm{n}$ is concomitant with budburst for Paris urban silver lindens. In diffuse-porous species, the start of radial growth is strongly linked to buds' activity and leaf expansion (Essiamah and Eschrich 1986). Moreover, this is consistent with the generally accepted idea that the initial growth phase strongly determines the annual increment (Bréda and Granier 1996; Deslauriers et al. 2007) and silver lindens, as for beech (Fagus sylvatica L.), could potentially have achieved between $30 \%$ to $70 \%$ of their annual increment by the end of June (Lebaube et al. 2000; Lebourgeois et al. 2005). On the other side, temperatures in May $n$ could reduce cambial activity. In their review, Begum et al. (2013) pointed out the importance of cumulated elevated temperatures from late winter to early spring, as affecting the timing of the initiation of cambial reactivation and xylem differentiation in tree stems.

Negative pointer years coincided with climatic extreme events. These extreme years are characterized by a high recurrence, during vegetative season, of strongly negative precipitation anomalies. The most relevant negative year occurred in 1976, recognized at European level as a severe drought year (Scharnweber et al. 2011; Météo France and Agence Parisienne du Climat 2015). According to precipitation anomalies during negative years (Fig. 5), it seems that the repetition of water deficit through the current vegetation period influences the observed low growth rates (Scharnweber et al. 2011). Characteristic droughts in 1976 and 2006 were described as quite similar with strong deficits in precipitation since the autumn n-1 until summer n (Météo France 2017). Thus, the drastically reduced growth we observed for these years is likely explained by the occurrence of strong precipitation deficits in winter $\mathrm{n}-1$ and spring $\mathrm{n}$, the latter determining earlywood formation and annual increment (Schwinning et al. 2005a, 2005b). However, as we also observed positive years directly following negative years (i.e. 1976/1977; 1998/1999), negative years seem to have short-term impact given that there is a fast recovery of growth after one year (Figs 3 and 5). This resilience highlights the efficient use of limited water resources by urban silver lindens that is a desirable trait for trees in dry environments like urban areas (Jaleel et al. 2008).

The negative correlation between growth and solar radiation in October $n-1$ could be explained by sunscalds, often observed by the Paris practitioners (pers. comm.). Switching from a 
transient freezing event to exposure to solar radiation would lead to a rapid freeze-thaw cycle leading to significant necrotic areas on the trunk, and predispose damaged trees to pathogen attacks (Manion 1991). Moreover, it is known that urban trees are more susceptible to bark temperature fluctuation than forest trees, which may be further increased by reflection from buildings, snow, and pavement (Tattar 1989). Finally, successive freeze-thaw cycles during winter have been shown to generate xylem embolism during the thaw step, and thus to alter next year's growth (Améglio et al. 2002; Charrier et al. 2015). However, excess of light during leaf senescence could also expose plant at risk of photoinhibitory conditions during autumnal leaf senescence. Severe photoinhibition may result in reduced resorption of critical foliar nutrients, which can significantly affect plant fitness (Hoch et al. 2003).

\section{Stability of the climate-growth relationships}

Taking into account possible changes in tree sensitivity to climate becomes increasingly important in climate-growth analyses (Wilmking and Myers-Smith 2008). The moving analysis of climate-growth relationships indicated that the relationships between precipitation in October n-1 and May n, and growth remained stable through the 1970-2013 period (Fig. 6). However for May n, only the BCC for the 19701999 period was significant. These results would indicate a recent change in this relation with May $\mathrm{n}$ precipitation while the relation with precipitation in October n-1 remained stable (Andreu et al. 2007; Olivar et al. 2015).

Remarkably, the significant relationships with temperature and solar radiations found in the global analysis for the 19702013 period appeared not significant in moving analysis, meaning that temperature-growth and solar radiation-growth relations were not stable through this period. This could be due to a quick change in temperature evolution in Paris, as a general increase of $0.3{ }^{\circ} \mathrm{C}$ per decade of both minimal and maximal temperatures has been observed since the second part of the twentieth century (Météo France and Agence Parisienne du Climat 2015). These results agreed with several dendrochronological researches that demonstrated a change in the response of tree growth to temperature over the last 40 to 50 years, possibly attributed to climate changes (Biondi 2011). Locally, the climatic projections for the 2071-2100 period in Paris suggest that summer conditions (June, July, August; $\mathrm{T}^{\circ} \mathrm{C}>25^{\circ} \mathrm{C}$ ) will last between 10 to 60 days longer while winter conditions (December, January, February; $\mathrm{T}^{\circ}<4{ }^{\circ} \mathrm{C}$ ) will last between 21 to 50 days shorter. Minimal and maximal temperatures could increase of about 1.1 to $4.3{ }^{\circ} \mathrm{C}$. There is a higher level of uncertainty concerning precipitations projections: they could increase in winter by 8 to $46 \%$ but also decrease in summer by 6 to 25\% (MétéoFrance and Agence Parisienne du Climat 2015). In the light of our results and climatic projections, the growth of urban silver lindens will likely decrease in the future.

\section{Conclusions and recommendations for management}

Water availability clearly appeared to be the main limiting factor of past growth of street trees. Younger urban silver lindens presented a high sensitivity to climate and the highest growth rate when compared to older classes. When compared with park trees, street trees had higher sensitivity but lower growth rates. Climatic and pointer years analyses pointed out the importance of drought characterization in order to understand its potential impact on tree functioning. In addition, precipitation occurring in autumn and spring mainly determined the amount of annual increment. Thus, as recommendations, an irrigation management, especially for 15 year-old trees and specifically in October and May, could optimize street tree functioning and survival. Finally, a stronger stability between growth and precipitation was only evidenced in October. For the other climatic factors, this study revealed an unstable relation and so, quick changes in growth-climate relationships over the last 40 years, underlying the increasing effect of climate change on urban ecosystem sustainability. Under climate change context, more long-term studies on street tree functioning are needed in order to follow and predict their future needs and behaviors in urban areas for adapted management practices.

Acknowledgements This project was funded and supported by the CDC Biodiversity and the ANR Ecoville (ANR-14-CE22-0021). The authors also acknowledge support by the French Government through the Investissements d'avenir (ANR-10-LABX-14-01) programme. We are especially grateful to the Mairie de Paris, Patricia Orsini, Beatrice Rizzo, Christophe Simonetti and his team of foresters for authorizing us to work on Paris street and park trees and for their priceless help during this study. We are very grateful to Alexa Dufraisse (UMR 7209) for allowing us to use a Lintab measurement table. At last, we would like to address a special thank to Claire Damesin for her precious help and advises on this study.

\section{Compliance with ethical standards}

Data accessibility Data will be available from the Dryad Digital Repository.

\section{References}

AirParif (2017) Bilan de la qualité de l'air en Ile-de-France https://www. airparif.asso.fr/etat-air/bilan-annuel

Allen RG, Pereira LS, Raes D, et al (1998) Crop evapotranspiration Guidelines for computing crop water requirements - FAO Irrigation and drainage paper 56. Irrig Drain 1-15

Améglio T, Bodet C, Lacointe A, Cochard H (2002) Winter embolism, mechanisms of xylem hydraulic conductivity recovery and 
springtime growth patterns in walnut and peach trees. Tree Physiol 22:1211-1220

Andreu L, Gitierrez E, Macias M et al (2007) Climate increases regional tree-growth variability in Iberian pine forests. Glob Chang Biol 13: 1-12. https://doi.org/10.1111/j.1365-2486.2007.01322.x

Apple JD, Manion PD (1986) Increment core analysis of declining Norway maples, acer platanoides. Urban Ecol 9:309-321. https:// doi.org/10.1016/0304-4009(86)90006-9

Apur (2010) Essai de bilan sur le développement des arbres d'alignement dans Paris - Analyse statistique

Barbaroux C, Bréda N (2002) Contrasting distribution and seasonal dynamics of carbohydrate reserves in stem wood of adult ring-porous sessile oak and diffuse-porous beech trees. Tree Physiol 22:12011210

Becker M (1989) The role of climate on present and past vitality of silver fir forests in the Vosges mountains of northeastern France. Can J For Res 19:1110-1117. https://doi.org/10.1139/x89-168

Begum S, Nakaba S, Yamagishi Y et al (2013) Regulation of cambial activity in relation to environmental conditions: understanding the role of temperature in wood formation of trees. Physiol Plant 147: 46-54. https://doi.org/10.1111/j.1399-3054.2012.01663.x

Biondi F (2011) Are climate-tree growth relationships changing in NorthCentral Idaho, U.S.A.? Arctic. Antarct Alp Res 32:111-116

Biondi F, Qeadan F (2008) Inequality in paleorecords. Ecology 89:10561067. https://doi.org/10.1890/07-0783.1

Biondi F, Waikul K (2004) DENDROCLIM2002: A C++ program for statistical calibration of climate signals in tree-ring chronologies. Comput Geosci 30:303-311. https://doi.org/10.1016/j.cageo.2003. 11.004

Blasing TJ, Solomon AM, Duvick DN (1984) Response Functions Revisited. Tree-Ring Bull 44:1-15

Bräker OU (2002) Measuring and data processing in tree-ring research -a methodological introduction. Dendrochronologia 20:203-216. doi: https://doi.org/10.1078/1125-7865-00017

Bréda N, Granier A (1996) Intra- and interannual variations of transpiration, leaf area index and radial growth of sessile oak stand (Quercus petraea). Ann Sci For 53:521-536

Briffa K, Jones P (1990) Basic chronology statistics and assessment. In: Methods of Dendrochronology: Applications in the Environmental Sciences. Kluwer Academic Publishers, pp 137-152

Capannelli G, Gollo E, Munari S, Ratto G (1977) Nitrogen oxides: Analysis of urban pollution in the city of genoa. Atmos Environ 11:719-727. https://doi.org/10.1016/0004-6981(77)90180-9

Carrer M, Urbinati C (2004) Age-dependent tree-ring growth responses to climate in Larix decidua and Pinus cembra. Ecology 85:730-740

Charrier G, Ngao J, Saudreau M, Améglio T (2015) Effects of environmental factors and management practices on microclimate, winter physiology, and frost resistance in trees. Front Plant Sci 6:1-18

Ciais P, Reichstein M, Viovy N et al (2005) Europe-wide reduction in primary productivity caused by the heat and drought in 2003. Nature 437:529-533. https://doi.org/10.1038/nature03972

Clark JR, Kjelgren R (1989) Water As a Limiting Factor in the Development of Urban Trees 1. 6:203-208

Clark JR, Matheny N (1992) Management of mature trees. Biol Conserv 62:145. https://doi.org/10.1016/0006-3207(92)90962-M

Cook ER, Kalriukstis LA (1990) Methods of Dendrochronology. Methods of Dendrochronology 97-104. doi: https://doi.org/10. 2307/1551446

Cook ER, Peters K (1981) The Smoothing Spline: A New Approach to Standardizing Forest Interior Tree-Ring Width Series for Dendroclimatic Studies. Tree-Ring Bull 41:45-53

Crippa M, El Haddad I, Slowik JG et al (2013) Identification of marine and continental aerosol sources in Paris using high resolution aerosol mass spectrometry. J Geophys Res Atmos 118:1950-1963. https://doi.org/10.1002/jgrd.50151
Cropper JP (1979) Tree-ring skeleton plotting by computer. Tree Ring Bull 39:47-59

Deslauriers A, Anfodillo T, Rossi S, Carraro V (2007) Using simple causal modeling to understand how water and temperature affect daily stem radial variation in trees. Tree Physiol 27:1125-1136. https://doi.org/10.1093/treephys/27.8.1125

Díaz-Porras DF, Gaston KJ, Evans KL (2014) 110 years of change in urban tree stocks and associated carbon storage. Ecol Evol 4:14131422. https://doi.org/10.1002/ece3.1017

Essiamah S, Eschrich W (1986) Water uptake in deciduous trees during winter and the role of conducting tissues in spring reactivation. IAWA J 7:31-38. https://doi.org/10.1163/22941932-90000435

Evans K (2010) Individual species and urbanisation. In: Urban Ecology. Cambridge University Press, pp 53-87

Fritts HC (1976) Tree rings and climate, The Blackb. Caldwell, New Jersey

Gillner S, Bräuning A, Roloff A (2014) Dendrochronological analysis of urban trees: Climatic response and impact of drought on frequently used tree species. Trees - Struct Funct 28:1079-1083. https://doi. org/10.1007/s00468-014-1019-9

Gillner S, Vogt J, Roloff A (2013) Climatic response and impacts of drought on oaks at urban and forest sites. Urban For Urban Green 12:597-605. https://doi.org/10.1016/j.ufug.2013.05.003

Gregg J, Jones C, Dawson T (2003) Urbanization effects on tree growth in the vicinity of New York City. Nature 183-187. doi: https://doi. org/10.1038/nature 01776.1

Grissino-Mayer HD (2001) Evaluating crossdating accuracy: A manual and tutorial for the computer program COFECHA. Tree-Ring Res 57:205-221. doi: S

Gruber A, Pirkebner D, Florian C, Oberhuber W (2012) Europe PMC Funders Group No evidence for depletion of carbohydrate pools in Scots pine ( Pinus sylvestris L . ) under drought stress. 14:142-148. doi: https://doi.org/10.1111/j.1438-8677.2011.00467.x.No

Guiot J (1991) The bootstrapped response function. Tree-Ring Bull 51: $39-41$

Gulyás Á, Unger J, Matzarakis A (2006) Assessment of the microclimatic and human comfort conditions in a complex urban environment: Modelling and measurements. Build Environ 41:1713-1722. https://doi.org/10.1016/j.buildenv.2005.07.001

Harris JR, Bassuk NL, Day SD (1994) Plant establishment and root growth. In: Watson GW, Neely D (eds) The Landscape Below Ground. International Society of Arboriculture, Savoy, pp 16-23

Jaleel CA, Gopi R, Sankar B et al (2008) Differential responses in water use efficiency in two varieties of Catharanthus roseus under drought stress. C R Biol 331:42-47. https://doi.org/10.1016/j.crvi.2007.11.003

Kjelgren RK, Clark JR (1992) Microclimates and tree growth in three urban spaces. J Environ Hortic 10:139-145 doi: Export Date 19 June 2013

Lebaube S, Le Goff N, Ottorini J-M, Granier A (2000) Carbon balance and tree growth in a Fagus sylvatica stand. Ann For Sci 57:49-61. https://doi.org/10.1051/forest:2000100

Lebourgeois F, Bréda N, Ulrich E, Granier A (2005) Climate-tree-growth relationships of European beech (Fagus sylvatica L.) in the French Permanent Plot Network (RENECOFOR). Trees - Struct Funct 19: 385-401

Lebourgeois F, Cousseau G, Ducos Y (2003) Étude d'une chênaie sessiliflore exceptionnelle : la Futaie des Clos (Sarthe). Rev For Française 55:333-346

Lin CJ, Wang SY, Yang TH, Tsai MJ (2006) Compressive strength of young Taiwania (Taiwania cryptomerioides) trees grown with different thinning and pruning treatments. J Wood Sci 52:337-341. https://doi.org/10.1007/s10086-005-0771-2

Linares JC, Taïqui L, Sangüesa-Barreda G et al (2013) Age-related drought sensitivity of Atlas cedar (Cedrus atlantica) in the Moroccan Middle Atlas forests. Dendrochronologia 31:88-96. https://doi.org/10.1016/j.dendro.2012.08.003 
Lu JWT, Svendsen ES, Campbell LK et al (2010) Biological, social, and urban design factors affecting young street tree mortality in New York City. Cities Environ 3:1-15

Mairie de Paris (2016) L'arbre à Paris http://www.paris.fr/arbres

Manion P (1991) Tree disease concepts. Prentice-Hall; Englewood Cliffs, New Jersey; USA

Marion L, Gričar J, Oven P (2007) Wood formation in urban Norway maple trees studied by the micro-coring method. Dendrochronologia 25:97-102

Mattheck C, Breloer H (1994) Field Guide for Visual Tree Assessment (Vta). Arboric J 18:1-23

Maurin V, DesRochers A (2013) Physiological and growth responses to pruning season and intensity of hybrid poplar. For Ecol Manag 304: 399-406. https://doi.org/10.1016/j.foreco.2013.05.039

Maxwell RS, Wixom JA, Hessl AE (2011) A comparison of two techniques for measuring and crossdating tree rings. Dendrochronologia 29:237-243. https://doi.org/10.1016/j.dendro.2010.12.002

McCarthy HR, Pataki DE (2010) Drivers of variability in water use of native and non-native urban trees in the greater Los Angeles area. Urban Ecosyst 13:393-414. https://doi.org/10.1007/s11252-010$0127-6$

Mérian P (2012a) Notice d'utilisation de l'application. CLIMAT 1-10

Mérian P (2012b) POINTER et DENDRO : deux applications sous R pour l'analyse de la réponse des arbres au climat par approche dendroécologique. Rev For Fr 64:789-798. https://doi.org/10. 4267/2042/51116

Mérian P, Pierrat JC, Lebourgeois F (2013) Effect of sampling effort on the regional chronology statistics and climate-growth relationships estimation. Dendrochronologia 31:58-67

MétéoFrance (2017) Comparaison des sécheresses de 2006 et 1976. http://www.meteofrance.fr/climat-passe-et-futur/evenementsremarquables/comparaison-des-secheresses-de-2006-et-1976

MétéoFrance, Agence Parisienne du Climat (2015) Le changement climatique à Paris : évolution du climat à Paris depuis 1900, quel climat futur? Paris

Meyer F (1982) Bäume in der Stadt, 2nd edn. Verlag Eugen Ulmer, Stuttgart

Michelot A, Bréda N, Damesin C, Dufrêne E (2012) Differing growth responses to climatic variations and soil water deficits of Fagus sylvatica, Quercus petraea and Pinus sylvestris in a temperate forest. For Ecol Manag 265:161-171. https://doi.org/10.1016/j.foreco. 2011.10.024

Moser A, Rahman MA, Pretzsch H et al (2016a) Inter- and intraannual growth patterns of urban small-leaved lime (Tilia cordata mill.) at two public squares with contrasting microclimatic conditions. Int $\mathrm{J}$ Biometeorol. https://doi.org/10.1007/s00484-016-1290-0

Moser A, Rötzer T, Pauleit S, Pretzsch H (2016b) The Urban Environment Can Modify Drought Stress of Small-Leaved Lime (Tilia cordata Mill.) and Black Locust (Robinia pseudoacacia L.) Forests 7:-71. https://doi.org/10.3390/f7030071

Neuwirth B, Schweingruber FH, Winiger M (2007) Spatial patterns of central European pointer years from 1901 to 1971. Dendrochronologia 24:79-89. https://doi.org/10.1016/j.dendro. 2006.05.004

Nielsen CN, Bühler O, Kristoffersen P (2007) Soil water dynamics and growth of street and park trees. Arboric Urban For 33:231-245

Oldfield EE, Warren RJ, Felson AJ, Bradford MA (2013) Challenges and future directions in urban afforestation. J Appl Ecol 50:n/a-n/a. doi: https://doi.org/10.1111/1365-2664.12124

Olivar J, Bogino S, Spiecker H, Bravo F (2015) Changes in climategrowth relationships and IADF formation over time of pine species (Pinus halepensis, P. pinaster and P. sylvestris) in Mediterranean environments. For Syst 24:10. https://doi.org/10.5424/fs/201524105885

Pataki DE, Carreiro MM, Cherrier J et al (2011) Coupling biogeochemical cycles in urban environments: ecosystem services, green solutions, and misconceptions. Front Ecol Environ 9:27-36. https://doi.org/10.1890/090220

Pellegrini P (2012) Pieds d'arbre, trottoirs et piétons : vers une combinaison durable ? Développement Durable Territ 3:1-16. https://doi.org/10.4000/developpementdurable.9329

Petersen A, Eckstein D (1988) Roadside Trees in Hamburg-Their Present Situation of Environmental Stress and Their Future Chance for Recovery. Arboric J 12:109-117. https://doi.org/10. 1080/03071375.1988.9756382

Quigley MF (2004) Street trees and rural conspecifics : Will long-lived trees reach full size in urban conditions? Urban Ecosyst 7:29-39. https://doi.org/10.1023/B:UECO.0000020170.58404.e9

R Development Core Team R (2011) R: A Language and Environment for Statistical Computing

Radoglou K, Dobrowolska D, Spyroglou G, Nicolescu VN (2009) A review on the ecology and silviculture of limes: (Tilia cordata Mill., Tilia platyphyllos Scop, and Tilia tomentosa Moench.) in Europe. Bodenkultur 60:9-19. http://www.valbro.uni-freiburg.de/

Rahman MA, Smith JG, Stringer P, Ennos AR (2011) Effect of rooting conditions on the growth and cooling ability of Pyrus calleryana. Urban For Urban Green 10:185-192. https://doi.org/10.1016/j.ufug. 2011.05.003

Rahman MA, Moser A, Rötzer T, Pauleit S (2017) Microclimatic differences and their influence on transpirational cooling of Tilia cordata in two contrasting street canyons in Munich, Germany. Agric For Meteorol 232:443-456. https://doi.org/10.1016/j.agrformet.2016.10.006

Roberts BR (1977) The response of urban trees to abiotic stress. J Arboric 3:75-78

Roberts J, Jackson N, Smith M (2006) Tree roots in the built environment. The Stationery Office, London

Roman LA (2014) How Many Trees Are Enough ? Tree Death And The Urban Canopy Scenariojournal 1-8

Roman LA, Scatena FN (2011) Street tree survival rates: Meta-analysis of previous studies and application to a field survey in Philadelphia, PA, USA. Urban For Urban Green 10:269-274. https://oi.org/10. 1016/j.ufug.2011.05.008

Sæbø A, Benedikz T, Randrup TB (2003) Selection of trees for urban forestry in the Nordic countries. Urban For Urban Green 2:101-114. https://doi.org/10.1078/1618-8667-00027

Scharnweber T, Manthey M, Criegee C et al (2011) Drought matters Declining precipitation influences growth of Fagus sylvatica L. and Quercus robur L. in north-eastern Germany. For Ecol Manag 262: 947-961. https://doi.org/10.1016/j.foreco.2011.05.026

Schweingruber FH (1996) Tree rings and environment. Dendroecology

Schweingruber FH (1990) Identification, presentation and interpretation of event years and pointer years in dendrochronology. Dendrochronologia 53:160

Schwinning S, Starr BI, Ehleringer JR (2005a) Summer and winter drought in a cold desert ecosystem (Colorado Plateau) part I: effects on soil water and plant water uptake. J Arid Environ 60:547-566. https://doi.org/10.1016/j.jaridenv.2004.07.003

Schwinning S, Starr BI, Ehleringer JR (2005b) Summer and winter drought in a cold desert ecosystem (Colorado Plateau) part II: effects on plant carbon assimilation and growth. J Arid Environ 61:61-78. https://doi.org/10.1016/j.jaridenv.2004.07.013

Sieghardt M, Mursch-Radlgruber E, Paoletti E, et al (2005) The abiotic urban environment: Impact of urban growing conditions on urban vegetation. In: Urban Forests and Trees: A Reference Book. pp 281-323

Simard S, Giovannelli A, Treydte K et al (2013) Intra-annual dynamics of non-structural carbohydrates in the cambium of mature conifer trees reflects radial growth demands. Tree Physiol 33:913-923. https:// doi.org/10.1093/treephys/tpt075

Sjöman H, Nielsen AB, Oprea A (2012) Trees for urban environments in northern parts of Central Europe - a dendroecological study in northeast Romania and Republic of Moldavia. Urban Ecosyst 15:267281. https://doi.org/10.1007/s11252-011-0187-2 
Takagi M, Gyokusen K (2004) Light and atmospheric pollution affect photosynthesis of street trees in urban environments

Tattar TA (1989) Diseases of Shade Trees. Elsevier

Vardoulakis S, Gonzalez-Flesca N, Fisher BE (2002) Assessment of traffic-related air pollution in two street canyons in Paris: implications for exposure studies. Atmos Environ 36:1025-1039. https:// doi.org/10.1016/S1352-2310(01)00288-6

Vico G, Revelli R, Porporato A (2014) Ecohydrology of street trees: design and irrigation requirements for sustainable water use. Ecohydrology 7:508-523. https://doi.org/10.1002/eco.1369

Wang SY, Chiu CM, Lin CJ (2003) Application of the drilling resistance method for annual ring characteristics: Evaluation of Taiwania (Taiwania cryptomerioides) trees grown with different thinning and pruning treatments. J Wood Sci 49:116-124

Wang X, Zhang Y, McRae DJ (2009) Spatial and age-dependent tree-ring growth responses of Larix gmelinii to climate in northeastern China. Trees - Struct Funct 23:875-885
Whitlow TH, Bassuk NL (1987) Trees in difficult sites. J Arboric 13:10-17 Whitlow TH, Bassuk NL, Reichert DL (1992) A 3-year study of water relations of urban street trees. J Appl Ecol 29:436-450. https://doi. org/10.1038/147742b0

Wigley TML, Briffa KR, Jones PD (1984) On the Average Value of Correlated Time Series, with Applications in Dendroclimatology and Hydrometeorology. J Clim Appl Meteorol 23:201-213

Wilmking M, Myers-Smith I (2008) Changing climate sensitivity of black spruce (Picea mariana Mill.) in a peatland-forest landscape in Interior Alaska. Dendrochronologia 25:167-175

Xie Y, Wang X, Silander JA (2015) Deciduous forest responses to temperature, precipitation, and drought imply complex climate change impacts. Proc Natl Acad Sci 112:13585-13590. https://doi.org/10. 1073/pnas.1509991112

Zhao S, Liu S, Zhou D (2016) Prevalent vegetation growth enhancement in urban environment. Proc Natl Acad Sci U S A 113:6313-6318. https://doi.org/10.1073/pnas.1602312113 